\title{
Some aspects of the insolvency of a citizen as a participant in family legal relations
}

\author{
Tatiana Efimtseva ${ }^{1,2, *}$, Evgeniya Zaika ${ }^{1}$, Anna Husainova ${ }^{1}$ \\ ${ }^{1}$ Orenburg State University, Orenburg 460018, Russian Federation \\ ${ }^{2}$ Orenburg Institute (Branch) of the Kutafin Moscow State Law University (MSLA), Orenburg \\ 460000, Russian Federation
}

\begin{abstract}
This article is devoted to the problems of bankruptcy of citizens who are in family legal relations. The problems in this area are due to the fact that most bankruptcy procedures against citizens end with the sale of the debtor's property, which leads to the fact that the persons involved in this case pursue various, sometimes directly opposite, goals. After all, if a citizen has insufficient funds and other property to settle obligations, the property interests of his creditors competing for the distribution of the bankruptcy estate among them are affected. On the contrary, its beneficiaries are interested in preserving the property of a bankrupt citizen, which inevitably entails the likelihood of various kinds of abuses aimed at creating the appearance of civil and family relations that did not exist in reality.
\end{abstract}

\section{Introduction}

The creation of the institution of insolvency of a citizen was based on the legal doctrine of "freshstart": a citizen gets the opportunity to get rid of debts if he provides his property to cover debts and settlements with creditors. For example, in the USA, a debtor "donates" all his existing property to creditors, being completely released from all obligations, but retains all future income [1]. That is why the institution of consumer bankruptcy is considered as a benefit for a conscientious citizen in many countries of the world, but not everywhere yet [2].

As noted by Pihu Mishra and Sushanta Kumar Das, all bankruptcy laws aim to secure an equitable division of the insolvent debtor's property among all his creditors, and, in the second place, to prevent on the part of the insolvent debtor conduct detrimental to the interests of his creditors. In other words, bankruptcy law seeks to protect the creditors, first, from one another and, secondly, from their debtor. A third object, the protection of the honest debtor from his creditors, by means of the discharge, is sought to be attained in some of the systems of bankruptcy, but this is by no means a fundamental feature of the law [3].

In Russian practice, the assessment of such bankruptcy is also ambiguous, despite the fact that the institution of bankruptcy of a citizen has already managed to gain popularity. According to Unified Federal Register of Legally Significant Information on the Facts of the

* Corresponding author: tve-26@mail.ru 
Activities of Legal Entities, Individual Entrepreneurs and Other Economic Entities (Fedresurs), the number of court decisions on bankruptcy of citizens, including individual entrepreneurs, increased from 29,014 to 42,718 in the first half of 2020 , that is by $47.2 \%$. In June 2020, the courts declared 11,483 people bankrupt -2.18 times more than in the same month last year [4].

\section{Research methodology}

The methodology is the main provisions of scientific knowledge, an objective approach to research, the principles of information reliability, an all-encompassing approach to coverage of events, stability and sustainability, logic, and consistency. This article uses general scientific methods, such as systems, functions, logic, and private scientific methods: formal logic, comparison, and specific sociology.

In particular, it compares the practical experience and legislation on bankruptcy of the Russian Federation and other countries. Information and data served as an experimental basis for this research work.

\section{Results}

Restoring the solvency of a natural person with the help of a bankruptcy institute must be an exceptional measure, and not a universally encouraged or desirable one. Ensuring the wellbeing of the society and the state requires the promotion of stable legal relations based on integrity, justice, morality, and other principles. Bankruptcy must not be artificially encouraged in order to make it available to as many people as possible. It is not always necessary to declare the bankruptcy of a natural person, as the primary objective should be the avoidance of bankruptcy. Therefore, there is a need to increase the impact of pre-trial debt counselling, where the debtor's economic situation shall be determined. However, if bankruptcy cannot be avoided, bankruptcy proceedings must be cheap, short, and simple, to provide an "earned fresh start" to the debtor [5].

In the general bankruptcy process of a debtor, such specific issues are often considered within the framework of separate disputes, as the exclusion of property from the debtor's bankruptcy estate, the establishment of creditors' claims secured by a mortgage, contesting transactions with the debtor's real estate, contesting transactions on the division of property of former spouses, and others. Based on the evidence presented and their assessment, the court establishes a balance of interests of the debtor and bankruptcy creditors, determining the appropriate amount of retention, as well as determining conditions favourable to all parties. The resolution of disputes on the exclusion of a particular property from the debtor's bankruptcy estate for the purpose of paying for the personal needs of dependent persons is carried out by the court according to the general rules of arbitration procedural legislation.

In the process of bankruptcy of a citizen, situations related to the disposal of the debtor's property are often considered. At the same time, the court must take into account the specific circumstances of the case, namely: the debtor's property status, the state registration of his marriage, the joint or separate residence of the spouses and their management of the common household, the conclusion of transactions with property, their orientation and legality, the presence of the debtor's dependents, etc. In the latter case, as a general rule, the court must ensure the participation of guardianship and guardianship authorities in the process. At the same time, it should be noted that sometimes this rule is applied in practice, these bodies are involved in court proceedings and enjoy the rights of a person participating in the case in the process, taking into account the specifics of bankruptcy legislation. 
However, consideration of certain categories of isolated disputes without actual and competent participation in the process of the guardianship and guardianship authority, without verification by this authority of the specific factual circumstances of the case may entail a significant violation of the rights and legitimate interests of minors and incapacitated persons dependent on the debtor.

Consequently, in this case, a situation arises when the guardianship and guardianship authority is unable to perform the public functions assigned to it during the bankruptcy procedure of a citizen, which negatively affects the interests of the debtor's dependents.

In this regard, it seems necessary to consolidate the procedural status of the guardianship and guardianship authority as a separate participant in the bankruptcy case and to make appropriate amendments to legislative acts concerning the competence of this authority.

\section{Discussion of the results}

At present, the issue of introducing property falling under the legal regime of joint ownership of married persons into the bankruptcy estate is relevant. A comprehensive analysis of the norms of the Civil Code of the Russian Federation and the Family Code of the Russian Federation allows us to conclude that the property of the spouses acquired in marriage is joint property, unless otherwise stipulated by the contract between them.

If the spouse's personal property is insufficient to repay creditors' claims for the spouse's personal obligations, the creditor has the right to demand the allocation of the debtor's share from the common property of the spouses. In accordance with the Federal Law of the Russian Federation of October 26, 2002 "On Insolvency (Bankruptcy)", part of the funds from the sale of the common property of spouses (former spouses) is included in the bankruptcy estate, corresponding to the citizen's share in such property, the rest of these funds is paid to the spouse (ex-spouse).

Thus, the spouse of the bankrupt debtor will be able to receive his share of the common property only after the sale of the property constituting the bankruptcy estate. This situation has received an ambiguous scientific assessment. For example, V.V. Vitryansky pointed out that "paragraph 7 of Article 213.26. of the Federal Law of the Russian Federation "On Insolvency (Bankruptcy)" violates the fundamental principles of regulating common property relations, including those related to foreclosure on a share in common property" [6]. Nevertheless, the legislation provides that a spouse who has common property with a bankrupt, in order to protect his interests, has the right to participate in resolving issues related to the sale of common property.

In addition, in order to respect the rights of the second spouse, it is necessary to divide the joint property of the spouses in court, and then only proceed to the stage of formation of the debtor's bankruptcy estate. At the same time, as noted in paragraph 7 of the Resolution of the Plenum of the Supreme Arbitration Court of the Russian Federation No. 63 dated December 23, 2010, "On some issues related to the application of Chapter III.1 of the Federal Law 'On Insolvency (Bankruptcy)'" [7], the spouse (former spouse) of the debtor has the right to demand in court the division of common property before its sale in bankruptcy proceedings, if the specified implementation does not take into account his interests, as well as his dependents, including minor children. The financial manager is necessarily involved in this case, and the creditors of the debtor are also entitled to participate as third parties. When considering this case, the spouse should strive to divide the common property in kind, and if this is not possible, then at least convince the court to deviate from the principle of equality of shares. Moreover, according to Paragraph 2 of Article 39 of the Family Code of the Russian Federation, the court has the right to depart from the beginning of equality of the spouses' shares in their common property based on the interests of minor children and (or) based on the noteworthy interest of one of the spouses, in particular, in cases where the other 
spouse did not receive income for disrespectful reasons or spent the spouses' common property to the detriment of the interests of the family.

A lot of transactions are made with the participation of actual spouses, including former ones. And if Part 3 of Article 19 of Federal Law of the Russian Federation "On Insolvency (Bankruptcy)" unambiguously refers to the debtor's affiliated persons his spouse, relatives in the direct ascending and descending line, sisters, brothers and their relatives in the descending line, parents, children, sisters and brothers of the spouse, then the actual spouses go beyond the scope of this concept, which, accordingly, complicates proving the fact of international transactions to the detriment of creditor's interests. It was noted in the literature that the legislation on insolvency (bankruptcy) does not include persons affiliated with the debtor who are in actual marital relations with him, which allows the debtor to hide his property from creditors with their help [8]. At the same time, the proposal to unambiguously include actual spouses or spouses who are in a registered marriage, but do not lead a joint household, among persons affiliated with the debtor does not correspond to the interests of bona fide participants in civil turnover, that is, spouses who did not participate in the concealment of the debtor's property [9].

In this regard, when considering a bankruptcy case of a citizen, it is the duty of the courts to conduct a more detailed study of all the circumstances of the case in comparison with an ordinary dispute, especially if such circumstances are referred to by persons participating in the case. This requires an analysis of not only direct, but also indirect evidence presented by the parties, as well as an assessment of their consistency with each other. In particular, courts need to pay attention to the following circumstances.

Firstly, the regime of the spouses' property is influenced by such a circumstance as the residence of the spouses [10]. So, for example, actual marital relations in which the debtor alienates the property of his de facto spouse through paid transactions may be equated to a legal marriage in the debtor's insolvency (bankruptcy) cases, and transactions made during the debtor's actual residence with another person may be invalidated on the grounds of their fictitiousness, provided that the managers and creditors provide convincing evidence.

The legal basis for refusing to satisfy the financial manager's claims is the court's conclusion that the presumption of the spouse's interest is refutable. Marital relations of persons who do not actually live together, do not run a joint household, are financially independent, but are connected by a record of the state of marriage, are a legal fiction. In the absence of actual content, a legal marriage does not imply a trusting relationship between the spouses, and therefore the presumption of interest in each other's affairs in relation to persons who have terminated family relations is not applicable. There are no grounds for applying paragraph 7 of Article 213.26. of the Federal Law of the Russian Federation "On Insolvency (Bankruptcy)" in such cases.

Secondly, in cases of challenging the debtor's transactions in the bankruptcy process, the court needs to establish facts directly confirming the commission of these transactions at the expense of the debtor's property, since the conclusion of transactions by interested parties does not mean that they were made at the expense of the debtor.

And, finally, the main burden when examining evidence in bankruptcy cases of citizens falls on the courts also because the legislator is quite indifferent to such a form of communication as an actual marriage, and these relations are not fully subject to family legal regulation.

At the same time, creditors and other interested persons have the right to challenge according to the rules of Chapter III.1 of the Federal Law of the Russian Federation "On Insolvency (Bankruptcy)" practically every transaction or other action committed at the expense of the debtor during the period of suspicion (including a prenuptial agreement, an agreement on the division of common property of spouses, etc.) [7], and, therefore, any transactions of actual spouses. Similarly, in the event of a breakup of the relationship, the 
cohabitants can protect their rights and divide the property by applying to the court with a claim for determining the size of the shares and the division of common shared ownership [11]. Moreover, cohabitation without marriage registration does not lead to a change in the property relations of the parties without proper evidence [12].

Jackie Gardina discusses the equal protection of citizens' rights in the bankruptcy process, regardless of whether the marriage is registered or not, in her work. When a bankruptcy court is interpreting and applying federal law with reference to state law, it should employ a federal choice of law rule. A federal choice of law rule ensures that the federal law will be interpreted in a manner consistent with congressional intent and avoids situations in which the federal law simply becomes a vehicle to promote individual states' policies. The proffered federal rule requires bankruptcy courts to choose a state law that is consistent with the bankruptcy policies, including ensuring that the parties' rights are not unnecessarily altered by the bankruptcy process. For parties whose rights are linked to a same-sex marriage or civil union, such a rule assures that their rights will not be adjudicated solely based on the sex of their partner, unduly altered by the "happenstance of bankruptcy," or subject to the shifting political sands within the forum state [13].

A completely different situation arises if the regime of the spouses' property is contractual, that is, in relation to the property acquired during the legal marriage, a marriage contract is valid, to which article 40 of the Family Code of the Russian Federation is devoted. Despite the fact that currently a prenuptial agreement is concluded quite often in practice, it does not guarantee the safety of one spouse's property as part of the bankruptcy procedure of the other spouse.

This is evidenced by numerous judicial practice on challenging such transactions. Thus, the court considered the case on the application of the financial manager for invalidation of the marriage contract, according to which the property acquired by the spouses during the marriage passed into the property of the spouse, while the spouse received only monetary claims. The court concluded that the execution of the marriage contract removes the property from the bankruptcy estate, which violates the rights of creditors, and declared the marriage contract invalid [14].

In the process of bankruptcy of a citizen, special attention should be paid to the presence of dependent minor children and citizens in need of guardianship and guardianship. After all, in this case, the question arises of ensuring the necessary functions of vital activity not only of the citizen himself, but also of persons dependent on him.

Without going into the details of the legal status of persons who are not able to independently perform actions and realize their legal consequences to one degree or another, S.B. Seletskaya states that both Roman common law and modern Civil law guard the property rights and interests of participants in economic turnover regardless of their mental state [15].

First of all, it should be noted that in case of bankruptcy of a citizen, children cannot be taken away from him, except in cases of a threat to their life or health. In addition, due to bankruptcy, parents cannot be restricted in parental rights or deprived of parental rights.

To participate in the bankruptcy case of a citizen who has dependent minor children or incapacitated persons, the guardianship and guardianship authorities, and sometimes the prosecutor, are necessarily involved. This is due to the specifics of the relations related to the insolvency of citizens, since the very fact that individuals are dependent on the debtor affects their rights a priori, and therefore it is necessary to ensure the protection of the rights of these persons by another independent entity unrelated to the debtor and its creditors.

As a result of the analysis of the regulatory framework and judicial practice, it becomes obvious that a citizen is significantly limited in matters of transactions in the interests of dependent minor children and citizens recognized as incapacitated as part of the debt 
restructuring procedure, and when the procedure for the sale of the debtor's property is introduced, his property capacity is fully transferred to the financial manager.

As for alimony paid by the debtor, they are not included in the bankruptcy estate, and the arbitration manager or the debtor's employer monthly transfers alimony to the recipient from the debtor's personal account. In case of bankruptcy of a citizen, the life of his dependents should not deteriorate, and it is for this reason that the financial manager is obliged to allocate a living wage for the debtor and his children. As a rule, half of the subsistence minimum per child is allocated, taking into account the rule that both parents must support the child. In the event that a child needs treatment, school fees and other reasonable costs for his existence, then all these issues can be resolved through a court ruling on the allocation of funds for these purposes. By analogy, the same rule applies to other dependents [16].

One of the most important issues in the bankruptcy of a citizen is the resolution of property disputes, and here it should be noted that child benefits, maternity payments, as well as children's property are not included in the bankruptcy estate, regardless of the form of this property and its value. Of course, parents as legal representatives can dispose of this property, but for many transactions it is necessary to obtain the prior consent of the guardianship and guardianship authorities.

When considering in the bankruptcy case of a citizen an application for challenging a debtor-citizen transaction affecting the rights of a minor or the rights of a person recognized by a court as incapacitated, the guardianship and guardianship authority is involved.

The guardianship and guardianship authority is obliged to give an opinion on the assessment of the consequences of invalidation of the transaction, including the possible deterioration of the rights of a minor or the rights of a person recognized by a court as incompetent (paragraph 5 of Article 213.32. of the Federal Law of the Russian Federation "On Insolvency (Bankruptcy)").

\section{Conclusion}

In conclusion, it should be noted that the presence of minor children or incapacitated persons dependent on the debtor significantly complicates the bankruptcy procedure of a citizen, since the financial manager in this case is obliged to withdraw funds intended to ensure the vital activity of these persons and transfer them to the debtor.

In addition, the protection of the rights of minors and persons deprived of legal capacity in the framework of civil proceedings is carried out through the participation of the prosecutor, as well as the guardianship and guardianship authority. However, in the arbitration process, including when considering the bankruptcy of a citizen, there are no legal grounds for the participation of the prosecutor, and the only participant in the process representing the public interests and interests of persons in need of protection is the guardianship and guardianship authority, which has limited powers, and whose employees are not always competent in bankruptcy matters. It turns out that the participation of guardianship and guardianship authorities in this area is purely formal, these bodies essentially perform the functions of an observer of compliance with the law in terms of the interests of dependents and, accordingly, act as participants in the bankruptcy procedure on their side.

At the same time, the court, when issuing judicial acts on bankruptcy cases of citizens, must take into account the legal rights of children and incapacitated persons, even in the case of suspended participation of guardianship and guardianship authorities.

In such circumstances, it is necessary to legislate the rule that monetary payments addressed to minor children or incapacitated persons, including alimony, pensions, allowances, maternity money and other mandatory payments, are not included in the bankruptcy estate and are credited to a special account opened by the debtor, from which he 
will be able to withdraw money independently, without the participation of a financial manager.

\section{References}

1. L. R. Badakhova, Some aspects of bankruptcy of citizens in the USA, Society and law, 4, 283-285 (2010)

2. I. N. Rozumovych, A. A. Luzik, Certain aspects of personal bankruptcy, Scientific notes of V.I. Vernadsky Crimean federal university. Juridical science, 4 (70), 208-212 (2018)

3. P. Mishra, S. Kumar Das, Social Ramifications of Bankruptcy Law, Insolvency and Bankruptcy Regime in India A Narrative, 83-93 (2020)

4. L. Gumenyuk, The fate of jointly acquired property in the bankruptcy of a spouse (2020). URL: $\quad$ https://www.advgazeta.ru/ag-expert/advices/sudba-sovmestno-nazhitogoimushchestva-pri-bankrotstve-supruga/

5. M. Schihalejev, T. Saarma, E. Draba, I. Strunkienè, Conditions for the Bankruptcy of Natural Persons: Which Baltic State is the Most Attractive for Bankruptcy? International Comparative Jurisprudence, 7(1), 100-114 (2021). DOI: http://dx.doi.org/10.13165/j.icj.2021.06.008

6. V.V. Vitryansky, Bankruptcy of citizens who are not individual entrepreneurs, Economy and law, 4, 3-29 (2015)

7. Resolution of the Plenum of the Supreme Arbitration Court of the Russian Federation No. 63 dated December 23, 2010 (as amended on July 30, 2013), "On some issues related to the application of Chapter III.1 of the Federal Law 'On Insolvency (Bankruptcy)"'. Access mode: http://www.consultant.ru

8. O. D. Osmanova, Kinship relations or properties as a tool for abuse in insolvency (bankruptcy), Entrepreneurial law, the application "Law and Business", 3 (2018)

9. L. B. Gudovicheva, L. Yu. Dobrynina, De Facto Marital Relations: Legal Significance and Consequences in Cases of Insolvency (Bankruptcy) of Individuals, Tomsk State $\begin{array}{llll}\text { University } & \text { Journal, } & \text { 440, 204-211 } & \text { (2019). }\end{array}$ https://doi.org/10.17223/15617793/440/28

10. Yu. B. Noskova, Yu. N. Kozlova, Joint property of spouses in the Russian Federation and the Republic of Uzbekistan: a comparative approach, Topical issues of civil law branches, Ural Law Institute of the Ministry of Internal Affairs of Russia (2018)

11. D. M. Dzutseva, E. S. Butaeva, Division of property acquired in de facto marital relations under the laws of the Russian Federation, Modern jurisprudence: current issues, achievements and innovations, Proceedings of the VI International Conference (Penza: MTsNS "Nauka i Prosveshchenie", 2018)

12. A. S. Nazarova, Legal regulation of de facto marital relations in the Russian Federation and the United States, Journal of Foreign Legislation and Comparative Law, 5 (60), 6063 (2016)

13. J. Gardina, The Perfect Storm: Bankruptcy, Choice of Law, and Same-Sex Marriage, Boston University Law Review, 86:881, 881-930 (2006)

14. Resolution of the Fifth Arbitration Court of Appeal dated January 16, 2020 in case No. A51-15138/2018 (2020). Access mode: http://www.consultant.ru

15. S. B. Seletskaya, About some features of the legal status of the legally disabled and incapacitated, Scientific Notes of Kazan University, Series: Humanities, 157 (6),151$158(2015)$ 
16. Resolution of the Plenum of the Supreme Court of the Russian Federation No. 48 dated December 25, 2018, "On some issues related to the peculiarities of the formation and distribution of the bankruptcy estate in bankruptcy cases of citizens". Access mode: http://www.consultant.ru 